\title{
Estimating the State of Population Gene Pools of the Specially Protected Helicopsis striata (Mollusca, Gastropoda, Pulmonata) Species Based on DNA Markers
}

\author{
E. A. Snegin \\ Belgorod State National Research University, Belgorod, 308015 Russia \\ e-mail:snegin@bsu.edu.ru \\ Received March 31, 2015; in final form, May 21, 2015
}

\begin{abstract}
Based on DNA markers (RAPD and ISSR), the state of gene pools of nineteen populations of the specially protected relict Helicopsis striata (Mollusca, Gastropoda, Pulmonata) species in conditions of the Central Russian Upland south was studied. The data obtained demonstrate a high degree of subdivision of the population $\left(\Phi_{\mathrm{st}}=0.404, G_{\mathrm{st}}=0.358\right)$ and an increased level of homozygosity in a number of groups inhabiting the industrial zone and steppe biotopes. A significant correlation between the intensity of the gene flow and geographical distances between populations $(R=0.571 \pm 0.052)$ was registered; this corresponds to isolation by the distance model. The effective size values calculated based on the subdivision indices were significantly lower than the similar effective size of the background mollusk species.
\end{abstract}

Keywords: terrestrial mollusk, population gene pool, anthropogenic altered landscape

DOI: $10.1134 /$ S2079059717020113

\section{INTRODUCTION}

The study on the state of natural populations of vulnerable species is currently one of the main directions for monitoring different territories. Such species include the Helicopsis striata Müller (steppe ribbed snail), which is recorded in the Red Book of Belgorod province (Red Book..., 2004), as well as in the protected lists of Poland, Czech Republic, and Slovakia (Ložek, 1980; Stępczak, 1999).

The area of the species covers the territory from Western and Middle Europe to Eastern Ukraine, and Kursk, Belgorod, and Voronezh provinces (Shileiko, 1978). Within the Central Russian Upland (along its eastern border), the species inhabits dry well-heated ravines, usually with the southern exposure with chalky soil. The species is mainly activity from April to May, as well as in September. A mass accumulation of mollusks can be observed in the habitats at this time. Snails spend the summer months buried in the soil.

The $H$. striata refers to the Mediterranean relict group of xerophilous mollusks (Nikolaev, 1973). The species is used as an indicator of dry steppefied ecosystems in the studies on the recovery of the historical past of European biocenoses (Sparks, 1953). At the Central Russian Upland territory, it is frequently a component of relict cenoses referred to as the "Lowered Alps" (Snegin, 2002).

Aim of the Study. Based on the analysis of the variability of the $R A P D$ - and $I S S R$ - DNA markers, to esti- mate the state of the $H$. striata populations at the eastern border of its species area for environmental purposes.

The relevance of this study is dictated by the necessity to pay close attention to relict communities of chalky outcrops that have been exposed to afforestation in recent years due to the implementation of the Green Capital regional program (this puts them on the brink of complete destruction).

\section{MATERIALS AND METHODS}

The tissue samples of the $H$. striata samples stored in a cryobank, which was created at the Laboratory of Population Genetics and Genotoxicology of Belgorod State National Research University, were the material used for the study. Samples from populations were taken during the expeditions from 2006 to 2010. In total, $694 \mathrm{H}$. striata individuals from nineteen populations were studied for their DNA loci (Fig. 1, Table 1).

The variability analysis was conducted using the polymerase chain reaction, including the random amplified polymorphic DNA (RAPD) (Welsh and McClelland, 1990) and inter simple sequence repeats (ISSR) (Zietkiewicz et al., 1994) methods. Two primers, including OPA 1 (5'-CAGGCCCTTC-3', RAPD method) and UBC 811 $\left(5^{\prime}-(\mathrm{GA})_{8} \mathrm{C}-3^{\prime}, I S S R\right.$ method), were used for the analysis. The amplification was conducted in the MJ Mini and MyCycler thermocyclers (Bio-Rad, United States). 


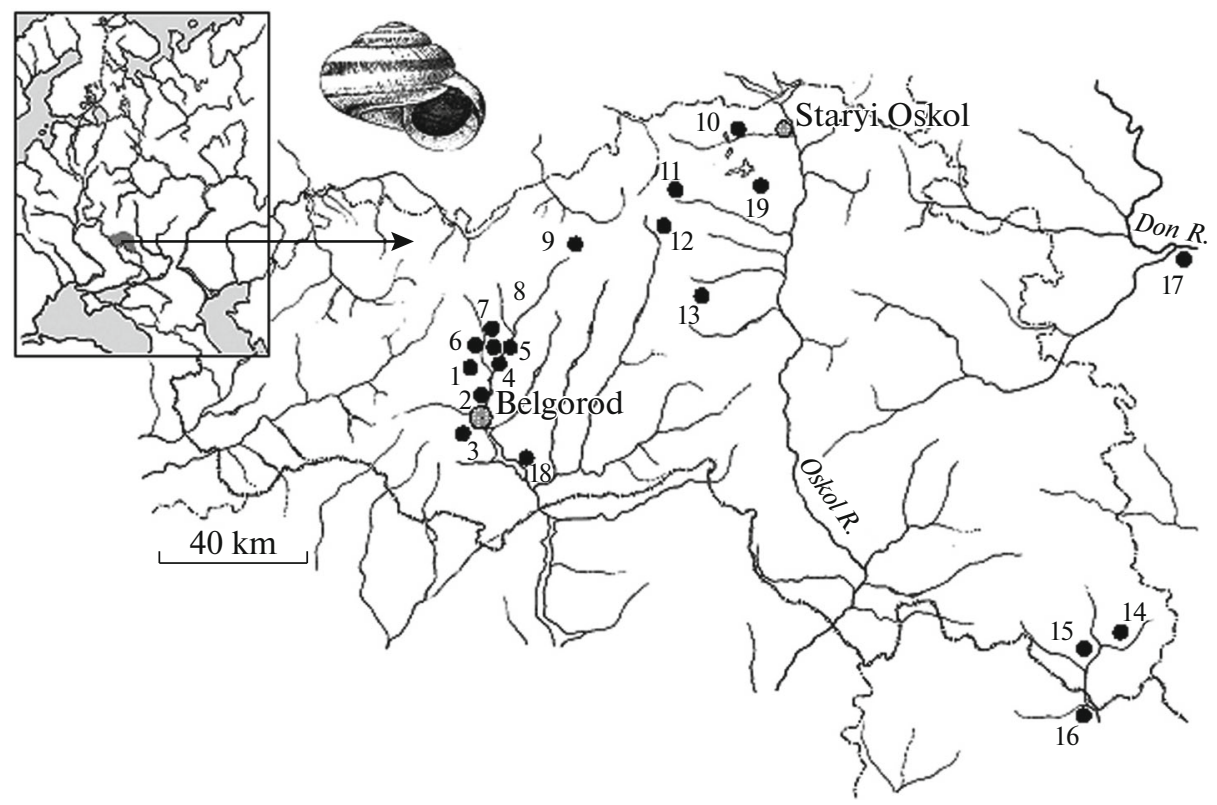

Fig. 1. Points of H. striata collections in the study region.

$R A P D$ method. The reaction was conducted in a $20 \mu \mathrm{L}$ mixture containing $20 \mathrm{ng}$ genomic DNA, PCR buffer (10 mM Tris- $\mathrm{HCl}(\mathrm{pH} 8.3), 50 \mathrm{mM} \mathrm{KCl}, 2 \mathrm{mM}$ $\mathrm{MgCl}_{2}$ ), $0.25 \mathrm{mM} \mathrm{dNTP}, 0.5 \mu \mathrm{M}$ primer, and 1 unit Taq DNA polymerase (inhibited for the hot start). The reaction was performed under the following conditions: "hot start" $\left(2 \mathrm{~min} / 94^{\circ} \mathrm{C}\right), 35$ cycles (denaturation $45 \mathrm{~s} / 94^{\circ} \mathrm{C}$, primer annealing $15 \mathrm{~s} / 36^{\circ} \mathrm{C}, 15 \mathrm{~s} / 45^{\circ} \mathrm{C}$, synthesis $1 \mathrm{~min} / 72^{\circ} \mathrm{C}$ ), additional synthesis $10 \mathrm{~min} / 72^{\circ} \mathrm{C}$, cooling to $4^{\circ} \mathrm{C}$.

$I S S R$ method. The reaction was conducted in a $25 \mu \mathrm{L}$ mixture containing 20 ng genomic DNA, a PCR buffer $\left(67 \mathrm{mM}\right.$ Tris- $\mathrm{HCl}(\mathrm{pH} 8.8), 16 \mathrm{mM}\left(\mathrm{NH}_{4}\right)_{2} \mathrm{SO}_{4}, 5 \mathrm{mM}$ $\beta$-mercaptoethanol, $7 \mathrm{mM}$ EDTA, $3 \mathrm{mM} \mathrm{MgCl}_{2}$ ), $0.25 \mathrm{mM}$ dNTP, $0.5 \mu \mathrm{M}$ primer, and 1 unit Taq DNA polymerase (inhibited for a hot start). The reaction was performed under the following conditions: hot start $\left(2 \mathrm{~min} / 94^{\circ} \mathrm{C}\right.$ ), 40 cycles (denaturation $30 \mathrm{~s} / 94^{\circ} \mathrm{C}$, primer annealing $30 \mathrm{~s} / 55^{\circ} \mathrm{C}$, synthesis $2 \mathrm{~min} / 72^{\circ} \mathrm{C}$ ), additional synthesis $10 \mathrm{~min} / 72^{\circ} \mathrm{C}$, cooling to $4^{\circ} \mathrm{C}$.

The PCR products were separated by electrophoresis in a $2 \%$ agarose gel using TAE buffer (cooled to $\left.+4^{\circ} \mathrm{C}\right), 10 \mathrm{~V} / \mathrm{cm}, 45 \mathrm{~min}$. The blocks were stained by ethidium bromide.

Binary matrixes, where the presence of a band was designated as " 1 " ( $p$ allele) and its absence as " 0 " ( $q$ allele $)$, were constructed according to the pictures of the amplified fragments obtained during the electrophoresis. Due to the fact that nonspecific amplification products can appear when using the RAPD method, clearly viewable and reproducible amplicons were used for the analysis. The repeated manifestation of amplificons after PCR in the same studied individuals was a criterion of reproducibility.
We isolated 17 loci in the $H$. striata using each of $O P A 1$ and $U B C 811$ primers. The obtained DNA patterns and their decoding are given in Fig. 2.

The data was processed using the GenAlEx (Peakall and Smouse, 2001), POPGENE 32 (Yeh et al., 2000), and MEGA5 (Tamura et al., 2011) programs. The Debec polygons were constructed by means of the Statistica 6.0 program.

\section{RESULTS AND DISCUSSION}

The Ewens-Watterson neutrality test of the used loci was conducted at the first stage (Ewens, 1972; Watterson, 1978; Manly, 1985); it demonstrated that there are no statistically significant differences between the observed homozygosity according to the Hardy-Weinberg and homozygosity expected in a neutral process for most alleles (on average 88.7\%) (Table 2).

We conducted the analysis of the genetic variability of the $H$. striata populations against the background of a comparison with the similar data that we previously obtained for two background terrestrial mollusk species (Bradybaena fruticum (bush snail) and Chondrula tridens (three dents snail)) inhabiting the studied region and being an indicator of the anthropogenic effects on ecosystems (Snegin, 2010, 2011a, 2011b, 2012, 2013).

The levels of genetic heterogeneity, as well as the graphical polygons of the studied populations (constructed using the $q$ allele frequencies), are given in Table 3 and Fig. 3. The data obtained demonstrate a picture similar to a large extent to the results that we previously obtained for the studied populations based 
Table 1. Description of the collection points

\begin{tabular}{|c|c|c|}
\hline Point no. & Description & Coordinates \\
\hline 1 & $\begin{array}{l}\text { Shopino, south-eastern slope of the right coast of the Lipovyi Donets river; depressive } \\
\text { motley grass meadows; chalky soils }\end{array}$ & $\begin{array}{l}50^{\circ} 42^{\prime} 20.17^{\prime \prime} \mathrm{N} \\
36^{\circ} 35^{\prime} 43.20^{\prime \prime} \mathrm{E}\end{array}$ \\
\hline 2 & $\begin{array}{l}\text { White mountain, vicinity of Belgorod, south-western steep chalky slope of the right } \\
\text { coast of the Severskii Donets river }\end{array}$ & $\begin{array}{l}50^{\circ} 37^{\prime} 28.66^{\prime \prime} \mathrm{N} \\
36^{\circ} 37^{\prime} 15.97^{\prime \prime} \mathrm{E}\end{array}$ \\
\hline 3 & $\begin{array}{l}\text { Botanical garden, vicinity of Belgorod, territory of Belgorod State University botanical } \\
\text { garden, chalky outcrops }\end{array}$ & $\begin{array}{l}50^{\circ} 35^{\prime} 30.20^{\prime \prime} \mathrm{N} \\
36^{\circ} 32^{\prime} 20.66^{\prime \prime} \mathrm{E}\end{array}$ \\
\hline 4 & $\begin{array}{l}\text { Petropavlovka A, chalky slope of south exposition in the place of the Lipovyi Donets } \\
\text { river inflow in the Severskii Donets river }\end{array}$ & $\begin{array}{l}50^{\circ} 41^{\prime} 32.48^{\prime \prime} \mathrm{N} \\
36^{\circ} 38^{\prime} 26.51^{\prime \prime} \mathrm{E}\end{array}$ \\
\hline 5 & $\begin{array}{l}\text { Petropavlovka B, right steep coast of Severskii Donets river, southwestern exposure, } \\
\text { at the place of a former chalky quarry }\end{array}$ & $\begin{array}{l}50^{\circ} 42^{\prime} 16.15^{\prime \prime} \mathrm{N} \\
36^{\circ} 39^{\prime} 29.89^{\prime \prime} \mathrm{E}\end{array}$ \\
\hline 6 & $\begin{array}{l}\text { Ternovka, slope of the right coast of the Lipovyi Donets river of the southern exposure; } \\
\text { clay soils; depleted vegetation }\end{array}$ & $\begin{array}{l}50^{\circ} 44^{\prime} 01.45^{\prime \prime} \mathrm{N} \\
36^{\circ} 35^{\prime} 46.02^{\prime \prime} \mathrm{E}\end{array}$ \\
\hline 7 & $\begin{array}{l}\text { Ternovka A, southeastern clay slope of the left coast of the Lipovyi Donets river close } \\
\text { to the highway }\end{array}$ & $\begin{array}{l}50^{\circ} 43^{\prime} 37.58^{\prime \prime} \mathrm{N} \\
36^{\circ} 36^{\prime} 44.09^{\prime \prime} \mathrm{E}\end{array}$ \\
\hline 8 & $\begin{array}{l}\text { Ternovka B, southeastern slope of the left coast of the Lipovyi Donets river, chalky } \\
\text { soils, motley grass-meadow vegetation }\end{array}$ & $\begin{array}{l}50^{\circ} 43^{\prime} 30.75^{\prime \prime} \mathrm{N} \\
36^{\circ} 36^{\prime} 58.84^{\prime \prime} \mathrm{E}\end{array}$ \\
\hline 9 & $\begin{array}{l}\text { Belenikhino, chalky slope of the left coast of the Sazhenskii Donets river of the south- } \\
\text { western exposure; cereal-motley grassy vegetation }\end{array}$ & $\begin{array}{l}50^{\circ} 54^{\prime} 41.87^{\prime \prime} \mathrm{N} \\
36^{\circ} 38^{\prime} 21.65^{\prime \prime} \mathrm{E}\end{array}$ \\
\hline 10 & $\begin{array}{l}\text { Gubkin, territory of Gubkin town; ravine slope of the southeastern exposure } \\
\text { with meadow-steppe motley grassy vegetation }\end{array}$ & $\begin{array}{l}51^{\circ} 17^{\prime} 50.56^{\prime \prime} \mathrm{N} \\
37^{\circ} 32^{\prime} 11.98^{\prime \prime} \mathrm{E}\end{array}$ \\
\hline 11 & $\begin{array}{l}\text { Melavoe, southeastern chalky slope of a ravine of the left coast of the Orlik river; cereal } \\
\text { motley grass }\end{array}$ & $\begin{array}{l}51^{\circ} 08^{\prime} 02.93^{\prime \prime} \mathrm{N} \\
37^{\circ} 25^{\prime} 05.72^{\prime \prime} \mathrm{E}\end{array}$ \\
\hline 12 & $\begin{array}{l}\text { Teleshovka, steep chalky left coast of the Korocha river; vegetation in a depressive state } \\
\text { due to cattle overgrazing }\end{array}$ & $\begin{array}{l}51^{\circ} 02^{\prime} 20.91^{\prime \prime} \mathrm{N} \\
37^{\circ} 17^{\prime} 06.22^{\prime \prime} \mathrm{E}\end{array}$ \\
\hline 13 & $\begin{array}{l}\text { Khmelevoe, lower regions of the chalky slopes of the southern exposure in the headwa- } \\
\text { ters of the Khalan' river basin }\end{array}$ & $\begin{array}{l}50^{\circ} 53^{\prime} 08.29^{\prime \prime} \mathrm{N} \\
37^{\circ} 27^{\prime} 38.97^{\prime \prime} \mathrm{E}\end{array}$ \\
\hline 14 & $\begin{array}{l}\text { Nagol'noe, chalky slopes of the southern exposure of the Sarma river right coast; } \\
\text { steppe vegetation; Aidarskii natural park }\end{array}$ & $\begin{array}{l}49^{\circ} 58^{\prime} 43.61^{\prime \prime} \mathrm{N} \\
38^{\circ} 57^{\prime} 33.69^{\prime \prime} \mathrm{E}\end{array}$ \\
\hline 15 & $\begin{array}{l}\text { Kalyuzhnyi yar, chalky ravine in the Aidar river floodplain, territory of the Aidar natu- } \\
\text { ral park }\end{array}$ & $\begin{array}{l}49^{\circ} 57^{\prime} 02.88^{\prime \prime} \mathrm{N} \\
38^{\circ} 53^{\prime} 49.32^{\prime \prime} \mathrm{E}\end{array}$ \\
\hline 16 & $\begin{array}{l}\text { Kreidyanaya mountain, eastern chalky slope of the right coast of the Aidar river; vicin- } \\
\text { ities of the Sharovka settlement, Luganskprovince, Ukraine }\end{array}$ & $\begin{array}{l}49^{\circ} 49^{\prime} 54.75^{\prime \prime} \mathrm{N} \\
38^{\circ} 53^{\prime} 47.71^{\prime \prime} \mathrm{E}\end{array}$ \\
\hline 17 & $\begin{array}{l}\text { Divnogor'e, right coast of the Don river of the northern exposure; territory of Divno- } \\
\text { gor'e natural park, Voronezhprovince }\end{array}$ & $\begin{array}{l}50^{\circ} 59^{\prime} 14.52^{\prime \prime} \mathrm{N} \\
39^{\circ} 20^{\prime} 00.50^{\prime \prime} \mathrm{E}\end{array}$ \\
\hline 18 & Rzhavets, area of railway embankment; gentle slope of Belgorod reservoir & $\begin{array}{l}50^{\circ} 59^{\prime} 14.52^{\prime \prime} \mathrm{N} \\
39^{\circ} 20^{\prime} 00.50^{\prime \prime} \mathrm{E}\end{array}$ \\
\hline 19 & $\begin{array}{l}\text { Yamskaya steppe, southeastern chalky slope with steppe vegetation; vicinities of the } \\
\text { Yamskaya steppe reserve land }\end{array}$ & $\begin{array}{l}51^{\circ} 10^{\prime} 07.54^{\prime \prime} \mathrm{N} \\
37^{\circ} 38^{\prime} 23.18^{\prime \prime} \mathrm{E}\end{array}$ \\
\hline
\end{tabular}




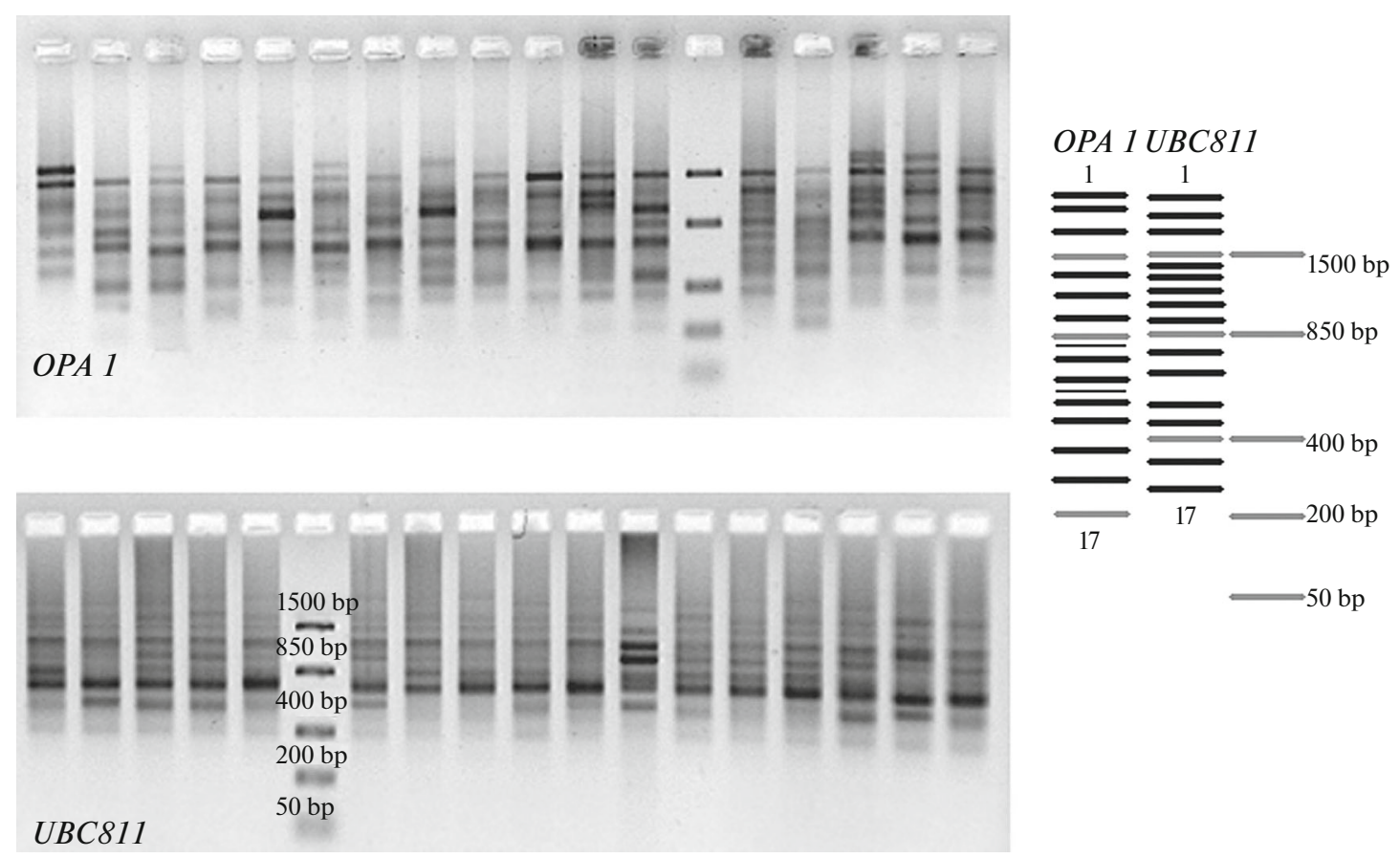

Fig. 2. H. striata RAPD and ISSR spectra.

on isoenzyme markers (Snegin and Sychev, 2011), according to which a decrease in the variability level occurs in the $H$. striata populations in the zones of influence of the Mining and Processing Plants (MPPs) related to the Kursk magnetic anomaly. Thus, the group from the Melavoe (no. 11) point was the most monomorphic according to all the DNA variability indices. A decreased variability was also registered at the Gubkin (no. 10), Teleshovka (no. 12), Khmelevoe (no. 13), and Yamskaya steppe (no. 19) points. The extreme fragmentation of the populations due to the active development of the territories adjacent to the MPPs (the creation of quarries, building of roads and overpasses) is apparently the cause of the homozygosity.

A similar decrease in heterozygosity was observed in the Nagol'noe (no. 14) and Kalyuzhnyi yar (no. 15) steppe biotopes ${ }^{1}$, where industrial territories are absent. This is probably caused by the fact that the isolation level of the mollusk populations in the steppe biome is high, since the amount of suitable biotopes in a more arid climate is smaller, and vast territories unsuitable for snails exist between them.

The analysis of molecular variance (AMOVA) (Excoffier et al., 1992) for the DNA loci (Table 4) detected a large disunity between the $H$. striata populations. Variability of $40 \%$ accounted for interpopulation differences, and the differentiation index $\Phi_{\mathrm{st}}=0.404$,

\footnotetext{
${ }^{1}$ The border between forest-steppe and steppe zones runs in the studied region. Most of the populations that we studied (except for $14,15,16$ ) are located in the forest-steppe biome).
}

while the gene flow intensity $N m=0.360$ individuals per generation. It should be noted that the degree of differences between populations was higher for allozyme markers (Snegin, 2012; Snegin, Sychev, 2011). The ratio of interpopulation dispersion (Vap) and intrapopulation dispersion ( $V w p)$ was $50 / 50 \%$, and $\Phi_{\mathrm{st}}=0.497, \mathrm{Nm}=0.288$.

These data significantly differ from similar indices obtained for the background mollusk species (Snegin, 2012). For example, for the Br. fruticum DNA loci, the level of population differentiation $\Phi_{\mathrm{st}}=0.298$ and the gene flow level $N m=0.708$, while the $V a p / V w p$ ratio $=$ $30 / 70 \%$. In the Ch. tridens, $\Phi_{\mathrm{st}}=0.185, \mathrm{Nm}=0.954$ and $V a p / V w p=19 / 81 \%$.

The estimation of the degree of the H. striata population differentiation based on the model suggested by M. Nei (1975) demonstrated a somewhat smaller disunity of the studied groups under conditions of the forest-steppe $\left(G_{\text {st }}=0.358\right)$ (Table 5). And the average gene flow was $\mathrm{Nm}=0.985$ for an individual per generation. This is mainly provided by the weaker distance between groups in the ISSR markers.

Among $R A P D$ markers, loci 4, 6, 8, and 14 are the most polymorphic; among ISSR markers, loci 4, 8, 10, and 13 are the most variable. The group of more monomorphic loci included loci 1, 9, 16, and 17 in the $O P A 1$ primer; loci 2, 9, and 17 in the $U B C 811$ primer. We note that the expected heterozygosity in the $R A P D$ loci $\left(H_{\mathrm{t}}=0.317 \pm 0.005\right)$ on average does not differ significantly from the heterozygosity in the ISSR loci $\left(H_{\mathrm{t}}=0.328 \pm 0.004\right)$. 
It is also known that the average $G_{\text {st }}$ values correspond to the level of genetic differentiation in a selectively-neutral process. In such a case, loci with larger $G_{\mathrm{st}}$ values most likely can experience the effect of disruptive selection, while loci with low values of the subdivision index are exposed to the effect of a stabilizing selection (The dynamics of population gene pools..., 2004). According to the data obtained, the largest differentiation between populations was registered for loci $O P A 1-1,-5,-10,-11,-12$, and $U B C$ 811-6.

The cluster analysis, whose results are shown in Fig. 4, demonstrated that the $H$. striata populations in the study region diverge in three geographically isolated groups. Only their population in Lugansk province (point 16) was an exception; according to the allele frequency ratio, it was closer to populations from the region of the Severskii Donets river headwaters (points 1-9 and 18).

It is possible that it is a consequence of either a genetic drift in this strongly isolated population or a sample error. It should be also noted that we observed such a picture of the population divergence by clusters (with small deviations) by the allozyme loci (Snegin, 2012; Snegin, Sychev, 2011).

The clustering data are to a large extent confirmed by a straightforward regression graph (Fig. 5), which demonstrates a significant correlation between the logarithms of the geographic distances $(D g)$ between groups and the logarithms of pairwise indices of the gene flow level $(\mathrm{Nm})$ calculated through pairwise differentiation indices $\Phi_{\mathrm{st}}\left(R_{\mathrm{DNA}}=0.571 \pm 0.052, t=10.9\right.$, $p<0.05)^{2}$. Previously, we obtained a similar picture for the allozymes $\left(R_{\mathrm{ALL}}=0.552 \pm 0.053, t=10.4, p<0.05\right)$. We note that this dependence is significantly higher than in the background Br. fruticum $\left(R_{\mathrm{ALL}}=0.059 \pm\right.$ $\left.0.063 ; R_{\mathrm{DNA}}=0.014 \pm 0.063\right)$ and Ch. tridens $\left(R_{\mathrm{ALL}}=\right.$ $\left.0.112 \pm 0.069 ; R_{\mathrm{DNA}}=0.085 \pm 0.069\right)$ species.

Based on the given data, it is possible to affirm that the $H$. striata population structure in the conditions prevalent south of the Central Russian Upland is more ordered and corresponds closer to isolation by the distance effect (Wright, 1943). This is probably associated with the peculiarities of the biology of this species exclusively dedicated to the communities of chalky outcrops and with limited possibilities of resettlement in conditions of a strongly fragmented landscape (this does not allow it to develop a metapopulation structure, which is typical for the background Br. fruticum and $C h$. tridens species). In addition, the presence of the isolation by the distance effect in the $H$. striata population structure can indicate in favor of a decrease in the role of a stabilizing (balanced) selection in populations of this species according to a number of selectively significant loci.

\footnotetext{
${ }^{2}$ This scheme for detecting isolation by the distance effect by selectively neutral genes between geographically and historically associated populations was suggested by M. Slatkin (1993).
}

Table 2. Results of the Ewens-Watterson test. Allele numbers according to the appropriate loci, according to which the observed homozygosity that differ from the expected $(P<0.05)$ are indicated. The data were calculated based on 1000 simulations of the main sample

\begin{tabular}{|c|c|c|c|}
\hline \multirow{2}{*}{ Population } & \multicolumn{2}{|c|}{ Alleles } & \multirow{2}{*}{$\%$ neutral loci } \\
\hline & $O P A 1$ & $U B C 811$ & \\
\hline 1 & $13,16,17$ & 1 & 79 \\
\hline 2 & No & No & 100 \\
\hline 3 & 16 & No & 94.8 \\
\hline 4 & No & No & 100 \\
\hline 5 & No & 15 & 94.8 \\
\hline 6 & 17 & 16 & 89.5 \\
\hline 7 & 10 & 9 & 89.5 \\
\hline 8 & 9 & $13,14,15$ & 79 \\
\hline 9 & 5 & 6,16 & 84.2 \\
\hline 10 & No & $2,7,12,15$ & 79 \\
\hline 11 & 2 & No & 94.8 \\
\hline 12 & 10,12 & No & 89.5 \\
\hline 13 & 6 & 5,14 & 84.2 \\
\hline 14 & $2,6,15$ & 1,9 & 73.7 \\
\hline 15 & No & 12 & 94.8 \\
\hline 16 & No & 1 & 94.8 \\
\hline 17 & 6,11 & 4,16 & 79 \\
\hline 18 & 1 & 14 & 89.5 \\
\hline 19 & No & 9 & 94.8 \\
\hline \multicolumn{3}{|c|}{ Mean } & 88.7 \\
\hline
\end{tabular}

The genetic similarity between populations within the groups, especially where an increased homozygosity is observed (in the MPP zone or in the steppe biotopes), is most likely provided not by the migration of individuals between populations but by the fact that the frequency of homozygous combinations for the same alleles increases in the $H$. striata populations under conditions of isolation (we previously demonstrated this based on the example of isoenzyme markers) (Snegin, 2012; Snegin, Sychev, 2011). The latter is probably provided by the similar natural selection vectors under similar conditions, as well as by the gene drift and genetic revolution processes in isolated groups, when the genes that are especially viable in the homozygous state (soloist genes) and are rare in open populations due to the domination of "well mixed genes” obtain a selective value (Mair, 1968).

We also used a straightforward regression equation based on the linear function coefficients between pairwise estimations of the gene flow and geographical 
Table 3. Measures of genetic heterogeneity in the $H$. striata populations averaged by the total DNA loci

\begin{tabular}{|c|c|c|c|c|c|c|}
\hline Point & $N$ & $\% P$ & $A$ & $A_{\mathrm{e}}$ & $I_{\mathrm{sh}}$ & $H_{\mathrm{e}}$ \\
\hline 1 & 31 & 82.35 & $1.82 \pm 0.07$ & $1.41 \pm 0.06$ & $0.363 \pm 0.046$ & $0.239 \pm 0.034$ \\
\hline 2 & 67 & 97.06 & $1.97 \pm 0.03$ & $1.44 \pm 0.06$ & $0.423 \pm 0.036$ & $0.272 \pm 0.028$ \\
\hline 3 & 48 & 91.18 & $1.91 \pm 0.05$ & $1.44 \pm 0.06$ & $0.418 \pm 0.038$ & $0.271 \pm 0.028$ \\
\hline 4 & 36 & 94.12 & $1.94 \pm 0.04$ & $1.42 \pm 0.05$ & $0.421 \pm 0.034$ & $0.27 \pm 0.025$ \\
\hline 5 & 20 & 82.35 & $1.82 \pm 0.07$ & $1.46 \pm 0.06$ & $0.41 \pm 0.043$ & $0.271 \pm 0.031$ \\
\hline 6 & 36 & 91.18 & $1.91 \pm 0.05$ & $1.47 \pm 0.06$ & $0.432 \pm 0.039$ & $0.283 \pm 0.029$ \\
\hline 7 & 31 & 88.24 & $1.88 \pm 0.06$ & $1.45 \pm 0.06$ & $0.407 \pm 0.042$ & $0.267 \pm 0.031$ \\
\hline 8 & 31 & 88.24 & $1.88 \pm 0.06$ & $1.45 \pm 0.06$ & $0.404 \pm 0.042$ & $0.265 \pm 0.032$ \\
\hline 9 & 32 & 79.41 & $1.79 \pm 0.07$ & $1.39 \pm 0.07$ & $0.348 \pm 0.046$ & $0.228 \pm 0.034$ \\
\hline 10 & 52 & 61.76 & $1.62 \pm 0.08$ & $1.22 \pm 0.05$ & $0.219 \pm 0.042$ & $0.137 \pm 0.029$ \\
\hline 11 & 31 & 17.65 & $1.18 \pm 0.07$ & $1.07 \pm 0.04$ & $0.069 \pm 0.031$ & $0.044 \pm 0.021$ \\
\hline 12 & 67 & 61.76 & $1.62 \pm 0.08$ & $1.25 \pm 0.06$ & $0.232 \pm 0.046$ & $0.150 \pm 0.032$ \\
\hline 13 & 28 & 55.88 & $1.56 \pm 0.09$ & $1.34 \pm 0.07$ & $0.295 \pm 0.05$ & $0.198 \pm 0.035$ \\
\hline 14 & 31 & 35.29 & $1.35 \pm 0.083$ & $1.16 \pm 0.05$ & $0.147 \pm 0.043$ & $0.097 \pm 0.029$ \\
\hline 15 & 31 & 32.35 & $1.32 \pm 0.08$ & $1.17 \pm 0.05$ & $0.151 \pm 0.042$ & $0.099 \pm 0.029$ \\
\hline 16 & 28 & 76.47 & $1.76 \pm 0.074$ & $1.45 \pm 0.06$ & $0.402 \pm 0.045$ & $0.268 \pm 0.032$ \\
\hline 17 & 34 & 64.71 & $1.65 \pm 0.08$ & $1.39 \pm 0.07$ & $0.333 \pm 0.051$ & $0.225 \pm 0.036$ \\
\hline 18 & 29 & 76.47 & $1.76 \pm 0.07$ & $1.33 \pm 0.05$ & $0.325 \pm 0.043$ & $0.207 \pm 0.030$ \\
\hline 19 & 31 & 50.00 & $1.50 \pm 0.09$ & $1.22 \pm 0.05$ & $0.222 \pm 0.044$ & $0.142 \pm 0.030$ \\
\hline \multicolumn{2}{|c|}{ Mean } & $69.81 \pm 5.26$ & $1.70 \pm 0.07$ & $1.34 \pm 0.06$ & $0.317 \pm 0.042$ & $0.207 \pm 0.030$ \\
\hline
\end{tabular}

$N$, number of analyzed individuals; $\% P$, percentage of polymorphic loci; $A$, average number of alleles per locus; $A_{\mathrm{e}}$, effective number of alleles; $I_{\mathrm{sh}}$, Shannon index; $H_{\mathrm{e}}$, expected heterozygosity.

Table 4. Results of the analysis of molecular variance (AMOVA) by the DNA loci in the H. striata populations

\begin{tabular}{|c|c|c|c|c|c|c|c|c|}
\hline Source of variability & $d f$ & $S S$ & $M S$ & $V$ & $\%$ & $\Phi_{\mathrm{st}}$ & $P$ & $\mathrm{Nm}$ \\
\hline Between populations & 18 & 1686.31 & 93.68 & 2.481 & $40 \%$ & \multirow{3}{*}{0.404} & \multirow{3}{*}{0.010} & \multirow{3}{*}{0.360} \\
\hline Within populations & 675 & 2466.96 & 3.65 & 3.655 & $60 \%$ & & & \\
\hline In total & 693 & 4153.27 & 97.34 & 6.136 & & & & \\
\hline
\end{tabular}

distances between populations for the effective size calculation:

$$
\log N m=a+b \log D g \text {. }
$$

Slatkin (1993) demonstrated that the efficient population size (for all the studied populations in general) can be obtained as $N e=10^{a}$, where $a$ is a coefficient obtained in the equation. The results of the calculations are given in Table 6. According to the data obtained, no significant differences in the effective size (calculated by the isoenzymes) were detected in three species. Significantly low values were found in the Br. fruticum relative to the effective size of the groups calculated based on the DNA markers.

We obtained a somewhat different result during the effective size calculation by means of an integral model based on the values of the population's subdivision index (Wright, 1951):

$$
F_{\mathrm{st}}=\frac{1-t_{k}}{1+t_{k}}
$$

where

$$
\begin{aligned}
t_{k}= & \exp -\left\{\left(\frac{1}{\mathrm{Ne}}\right)[\ln (K-0.5)+0.5772]\right. \\
& +\left(\frac{1}{2 \mathrm{Ne}^{2}}\right)\left[1.6449-\frac{2}{2 K-1}\right] \\
& \left.+\left(\frac{1}{3 \mathrm{Ne}^{3}}\right)\left[1.202-\frac{2}{(2 K-1)^{2}}\right]\right\},
\end{aligned}
$$

where $K$ is the number of populations used. 


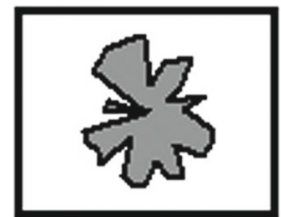

1. Shopino

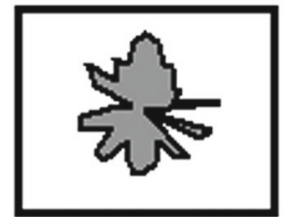

6. Ternovka

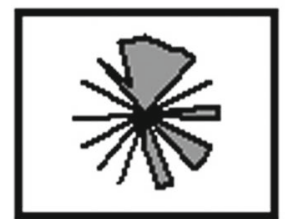

11. Melavoe

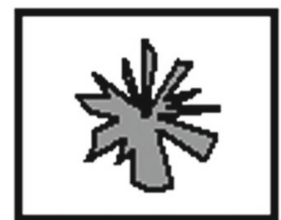

16. Kreidyanaya mountain

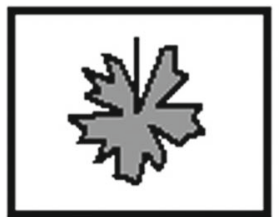

2. White mountain

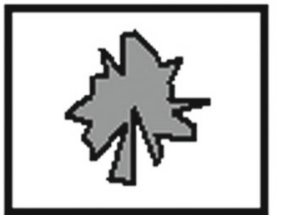

7. Ternovka A

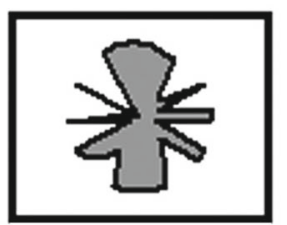

12. Teleshevka

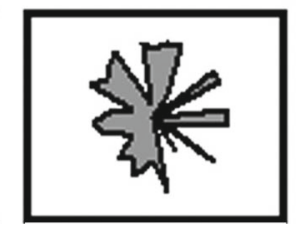

17. Divnogor'e

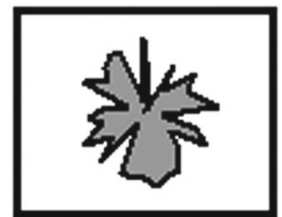

3. Botanical garden

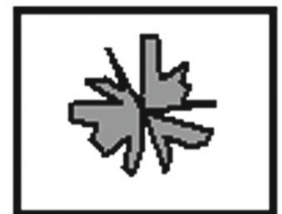

8. Ternovka B

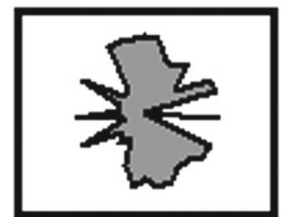

13. Khmelevoe

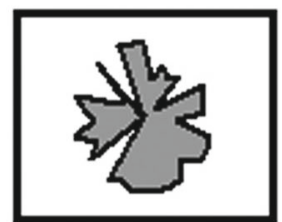

18. Rzhavets

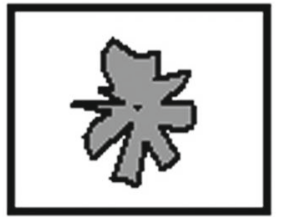

4. Petropavlovka A

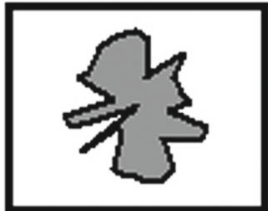

9. Belenikhino

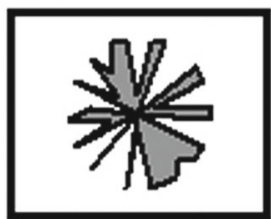

14. Nagol'noe

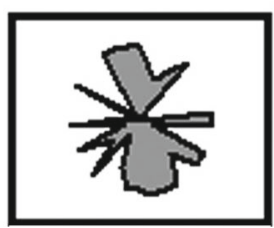

19. Yamskaya steppe

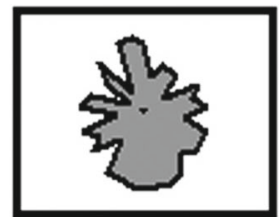

5. Petropavlovka B

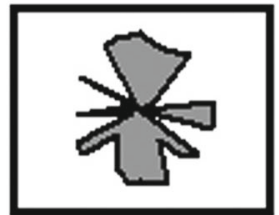

10. Gubkin

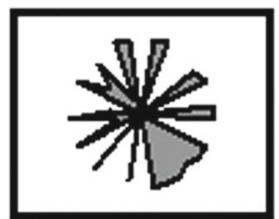

15. Kalyuzhnyi yar

Fig. 3. Diagrams constructed according to the total q allele frequencies for 34 DNA loci in the $H$. striata populations.

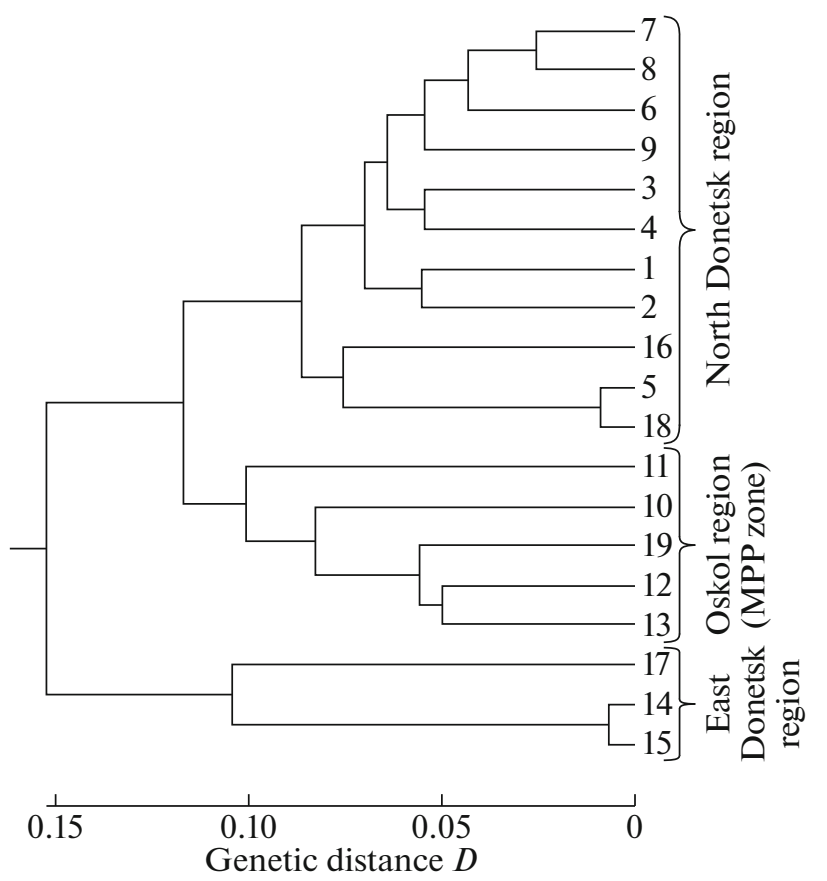

Fig. 4. Dendrogram of genetic distances according to Nei (1972) (UPGMA) between $H$. striata populations by the DNA loci. 
Table 5. Indices of the genetic differentiation of the $H$. striata studied groups by the DNA loci (according to Nei, 1975)

\begin{tabular}{|c|c|c|c|c|c|}
\hline Locus & No. & $H t$ & $H s$ & $G_{\mathrm{st}}$ & $\mathrm{Nm}$ \\
\hline \multirow{17}{*}{$O P A 1$} & 1 & 0.210 & 0.062 & 0.703 & 0.21 \\
\hline & 2 & 0.231 & 0.184 & 0.204 & 1.95 \\
\hline & 3 & 0.324 & 0.254 & 0.217 & 1.80 \\
\hline & 4 & 0.477 & 0.341 & 0.284 & 1.26 \\
\hline & 5 & 0.445 & 0.211 & 0.526 & 0.45 \\
\hline & 6 & 0.498 & 0.313 & 0.371 & 0.85 \\
\hline & 7 & 0.381 & 0.249 & 0.347 & 0.94 \\
\hline & 8 & 0.452 & 0.297 & 0.344 & 0.95 \\
\hline & 9 & 0.123 & 0.094 & 0.236 & 1.62 \\
\hline & 10 & 0.447 & 0.201 & 0.551 & 0.41 \\
\hline & 11 & 0.468 & 0.144 & 0.692 & 0.22 \\
\hline & 12 & 0.264 & 0.110 & 0.585 & 0.35 \\
\hline & 13 & 0.151 & 0.120 & 0.203 & 1.97 \\
\hline & 14 & 0.469 & 0.334 & 0.288 & 1.24 \\
\hline & 15 & 0.376 & 0.247 & 0.342 & 0.96 \\
\hline & 16 & 0.053 & 0.048 & 0.103 & 4.33 \\
\hline & 17 & 0.019 & 0.018 & 0.028 & 17.43 \\
\hline \multirow{17}{*}{$U B C 811$} & 1 & 0.245 & 0.166 & 0.320 & 1.06 \\
\hline & 2 & 0.177 & 0.110 & 0.375 & 0.83 \\
\hline & 3 & 0.355 & 0.213 & 0.399 & 0.75 \\
\hline & 4 & 0.445 & 0.338 & 0.240 & 1.58 \\
\hline & 5 & 0.391 & 0.245 & 0.374 & 0.84 \\
\hline & 6 & 0.457 & 0.229 & 0.500 & 0.50 \\
\hline & 7 & 0.246 & 0.179 & 0.271 & 1.35 \\
\hline & 8 & 0.499 & 0.347 & 0.304 & 1.14 \\
\hline & 9 & 0.161 & 0.132 & 0.182 & 2.25 \\
\hline & 10 & 0.500 & 0.364 & 0.272 & 1.34 \\
\hline & 11 & 0.392 & 0.268 & 0.316 & 1.08 \\
\hline & 12 & 0.260 & 0.190 & 0.269 & 1.36 \\
\hline & 13 & 0.484 & 0.381 & 0.212 & 1.86 \\
\hline & 14 & 0.426 & 0.279 & 0.343 & 0.96 \\
\hline & 15 & 0.288 & 0.186 & 0.354 & 0.91 \\
\hline & 16 & 0.198 & 0.129 & 0.347 & 0.94 \\
\hline & 17 & 0.057 & 0.052 & 0.097 & 4.65 \\
\hline \multicolumn{2}{|l|}{ Mean } & $0.323 \pm 0.021$ & $0.207 \pm 0.010$ & 0.358 & 0.895 \\
\hline
\end{tabular}

$G_{\text {st }}$, portion of interpopulation gene diversity in the total diversity; $H t$, expected portion of heterozygous genotypes in the general population, intrapopulation diversity value mean for all subpopulations; $\mathrm{Nm}$, average gene flow per generation. 


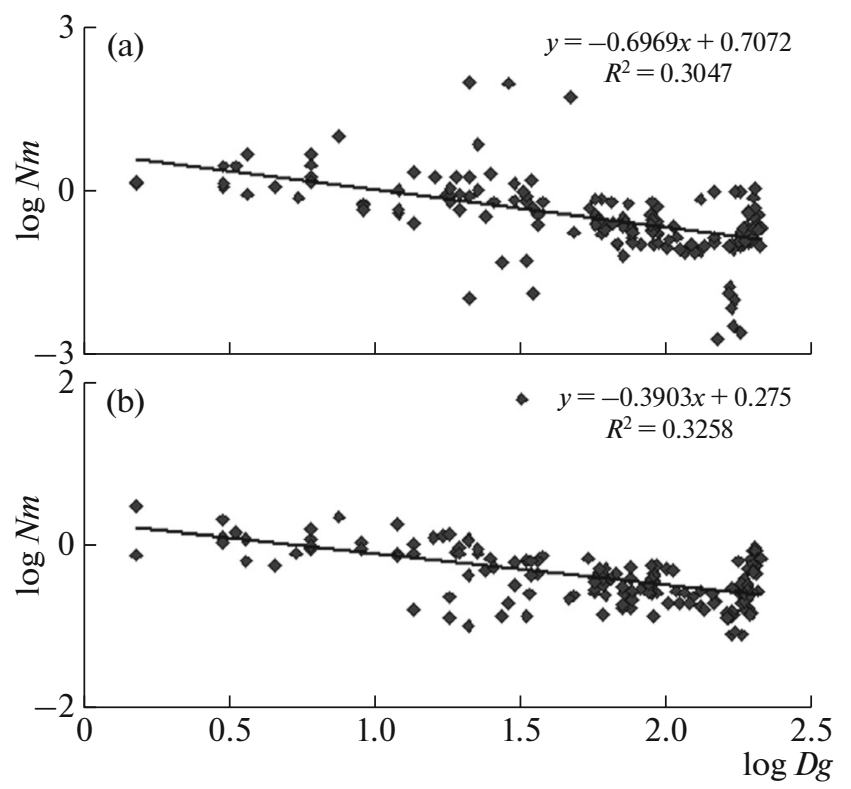

Fig. 5. Linear regression of the gene flow $(\mathrm{Nm})$ logarithm between pairs of $H$. striata populations in the logarithm of the genetic distance between them $(D g)$ (a, by allozymes (Snegin and Sychev, 2011); b, by the DNA markers).

Since two other integral and interchangeable indices $\left(G_{\mathrm{st}}\right.$ and $\left.\Phi_{\mathrm{st}}\right)$ were involved instead of the $F_{\mathrm{st}}$ index for determining the degree of the population's subdivision in this work, we found it possible to modify the indicated formula, by alternately introducing the values of these indices. It should be noted that we took the experience of such manipulations from the work on determining the effective size of the $C$. vindobonen- sis population inhabiting the territory of Nikolaev town (Kramarenko and Kramarenko, 2010).

The results of the calculations are given in Table 7. Among the mollusk species, the Ch. tridens has the largest effective size of populations; and the Br. fruticum is slightly inferior to it. The effective size values in the $H$. striata populations were significantly lower than in the first two species.

Table 6. Effective size values calculated based on the coefficients of the linear function between pairwise estimations of the gene flow $(\mathrm{Nm})$ and the geographic distance between samples

\begin{tabular}{l|c|c|c|c}
\hline \multirow{2}{*}{\multicolumn{1}{c|}{ Species }} & \multicolumn{2}{|c|}{ Isoenzymes } & \multicolumn{2}{c}{ DNA markers } \\
\cline { 2 - 5 } & $N e$ & Confidence interval $(\beta=0.95)$ & $N e$ & Confidence interval $(\beta=0.95)$ \\
\hline B. fruticum & 4.1 & $2.2-7.6$ & 0.57 & $0.39-0.83$ \\
\hline Ch. tridens & 3.8 & $2.6-5.7$ & 1.2 & $0.8-1.8$ \\
\hline H. striata & 5.1 & $2.6-10.0$ & 1.9 & $1.3-2.7$ \\
\hline
\end{tabular}

Table 7. Effective size values in the populations of different species calculated based on subdivision indices $\left(F_{\mathrm{st}}, G_{\mathrm{st}}\right.$, and $\left.\Phi_{\mathrm{st}}\right)$

\begin{tabular}{c|c|c|c}
\hline \multicolumn{1}{c|}{ Index } & $\begin{array}{c}\text { Br. fruticum } \\
(K=35)\end{array}$ & $\begin{array}{c}\text { Ch. tridens } \\
(K=25)\end{array}$ & $\begin{array}{c}\text { H. striata } \\
(K=19)\end{array}$ \\
\hline $\mathrm{Ne}\left(F_{\mathrm{st}}\right.$ by allozymes $)$ & 9.2 & 10.5 & 4.9 \\
\hline $\mathrm{Ne}\left(\Phi_{\mathrm{st}}\right.$ by allozymes $)$ & 7.0 & 6.2 & 3.5 \\
\hline $\mathrm{Ne}\left(G_{\mathrm{st}}\right.$ by DNA $)$ & 7.3 & 10.3 & 4.9 \\
\hline $\mathrm{Ne}\left(\Phi_{\mathrm{st}}\right.$ by DNA $)$ & 6.2 & 9.9 & 4.4 \\
\hline $\mathrm{Mean}$ & $7.4 \pm 0.6$ & $9.2 \pm 1.0$ & $4.4 \pm 0.3$ \\
\hline
\end{tabular}




\section{CONCLUSIONS}

Thus, the $H$. striata population structure in the studied region is more consistent with the natural historically developed structure. ${ }^{3}$ The $H$. striata could have penetrated the Central Russian Upland in the era of the subboreal Holocene. The modern populations of this species have preserved the allelic potential, which was typical for a virgin forest-steppe landscape. Therefore, the genetic processes in the $H$. striata populations (due to itsstenotopic) can probably be better indicators of the succession changes occurring in natural communities than could be expected using the eurybiontic background species (that actively adapt to human influence) for these purposes. In addition, there is a fear that isolated groups of this relict species could become extinct in conditions of anthropogenic insularization, with the currently ongoing destruction of unique chalky biotopes, against the background of a significant decrease in allelic diversity (especially in industrial zones).

\section{REFERENCES}

Dinamika populyatsionnykh genofondov pri antropogennykh vozdeystviyakh (Population Dynamics of Gene Pools under Anthropogenic Impacts), Altukhov, Y.P., Ed., Moscow: Nauka, 2004.

Ewens, W., The sampling theory of selectively neutral alleles, Theor. Pop. Biol., 1972, no. 3, pp. 87-112.

Excoffier, L., Smouse, P.E., and Quattro, J.M., Analysis of molecular variance inferred from metric distances among DNA haplotypes: Application to human mitochondrial DNA restriction data, Genetics, 1992, no. 131, pp. 479-491. Kramarenko, S.S. and Kramarenko, A.S., Allozimes and RAPD polymorphism of land molluscs Brephulopsis cilindrica (Enidae) in the natural and urbanized habitats of the south of Ukraine, Vidovye populyatsii I soobshchestva v antropogenno transformirovannykh landshaftakh: Sostoyanie i metody ego diagnostiki, Materialy XI mezhdunarodnoi nauchno-prakticheskoi konferentsii (Populations of Species and Communities in the Anthropogenically Transformed Landscapes: The State and Methods of Diagnostics, Proc. XI Int. Sci.-Pract. Conf.), Belgorod: IPC Politerra, pp. 210-211.

Krasnaya kniga Belgorodskoy oblasti (The Red book of the Belgorod province), Prisnyi, A.V., Ed., Belgorod, 2004.

Ložek, V., Z červené knihy našich měkkýšů - suchomilka Helicopsis striata, Z̈iva Acad. Praha, 1980, vol. 28, no. 6, p. 223.

Manly, B.F.J., The Statistics of Natural Selection on Animal Populations, London: Chapman and Hall, 1985.

Mayr, E., Animal Species and Evolution, Belknap Press, 1963.

Nei, M., Molecular Population Genetics and Evolution, Amsterdam, 1975.

Nei, M., Genetic distance between populations, Am. Nat., 1972, vol. 106, no. 949, pp. 283-292.

Nikolaev, V.A., Terrestrial mollusks of Mid-Russian Upland, Extended Abstract of Cand. Sci. (Biol.) Dissertation, Orel, 1973.

Peakall, R. and Smouse, P.E., GenAlEx V5: Genetic Analisis in Excel. Population genetic software for teaching

\footnotetext{
${ }^{3}$ The same cannot be said about the population of two other background species of terrestrial mollusks ( $B r$. fruticum and $C h$. tridens). The metapopulation structure of these species is mainly supported by their euribiontity and the effect of anthropogenic factors (anthropochore etc.) (Snegin, 2012).
}

and research, Canberra: Australian National University. http://www.anu.edu.au./BoZo/GenAlEx/.

Shileiko, A.A., Terrestrial molluscs of superfamily Helicoidea, Fauna SSSR, Molluski, 1978, vol. 3, no. 6.

Slatkin, M., Isolation by distance in equilibrium and nonequilibrium populations, Evolution, 1993, vol. 47, no. 1, pp. 294-279.

Snegin, E.A. and Sychev, A.A., Estimation of population viability of populations of specially protected species Helicopsis striata Müller (Mollusca, Gastropoda, Pulmonata) in the south of the Mid-Russian Upland), Teor. Prikl. Ekol., 2011, no. 2, pp. 84-93.

Snegin, E.A., Analysis of genetic variability in populations of a terrestrial snail Chondrula tridens Müll. (Gastropoda, Pulmonata), based on the RAPD and ISSR markers, Russ. J. Genet., Appl. Res., 2014, vol. 4, no. 5, pp. 444-454.

Snegin, E.A., Analysis of genetic variability of populations of terrestrial mollusk Bradybaena fruticum Müll. Using RAPD and ISSR markers, Nauchn. Vedomosti Belgorod. Gos. Univ., Ser. Estestv.Nauki, 2011b, no. 15 (110), pp. 37-43.

Snegin, E.A., Application of species of terrestrial molluscs as indicators of relict cenoses, Byull. Zhitomir Pedag. Univ., 2002 , vol. 10 , pp. $128-129$.

Snegin, E.A., Assessment of the state of population gene pools of terrestrial mollusks in conditions of influence of ore dressing combines from the example of Bradybaena fruticum Müll. (Gastropoda, Pullmonata), Russ. J. Genet., Appl. Res., 2011a, vol. 1, no. 5, pp. 379-389.

Snegin, E.A., Extensional and temporal aspects of ecological and genetic structure of populations of invertebrates (on the example of land snails and insects of the South Mid-Russian Upland)), Doctoral (Biol.) Dissertation, Belgorod, 2012.

Snegin, E.A., The genetic structure of model species populations of terrestrial mollusks in conditions of urbanized landscape using the example of Chondrula tridens Müll. (Gastropoda, Pulmonata), Russ. J. Genet., Appl. Res., 2012, vol. 2, no. 2, pp. 160-170.

Sparks, B.W., The former occurrence of both Helicella striata (Müller) and H. geyeri (Soós) in England, J. Conchol., 1953, vol. 23, pp. 372-378.

Stępczak, K., Aktualny stan występowania Helicopsis striata (O. F. Müller, 1774) w dolinie Odry (Mollusca: Gastropoda) w Polsce, Bad. Fizjogr. Pol. Zach., 1999, vol. 46, pp. 7-21.

Tamura, K., Peterson, D., Peterson, N., et al., MEGA5: Molecular Evolutionary Genetics Analysis using Maximum Likelihood, Evolutionary Distance, and Maximum Parsimony Methods. Molecular Biology and Evolution, 2011. http://www.kumarlab.net/publications.

Watterson, G., The homozygosity test of neutrality, Genetics, 1978, vol. 88, pp. 405-417.

Welsh, J. and McClelland, M., Fingerprinting genomes using PCR with arbitrary primers, Nucleic Acids Res., 1990, vol. 18, no. 22, pp. 7213-7219.

Wright, S., Isolation by distance, Genetics, 1943, vol. 28, pp. 114-138.

Wright, S., The genetical structure of populations, Ann. Eugenics, 1951, no. 15, pp. 323-354.

Yeh, F.C., Yang, R., Boyle, T.J., et al., POPGENE 32, Microsoft Window-based Freeware for Population Genetic Analysis, Version 1.32; Molecular Biology and Biotechnology Centre, University of Alberta: Edmonton, 2002. http://www.ualberta.ca/ fyeh/popgene_download.html.

Zietkiewicz, E., Rafalski, A., and Labuda, D., Genome fingerprinting by simple sequence repeat (SSR)-anchored polymerase chain reaction amplification, Genomics, 1994, vol. 20 , no. 2 , pp. $176-181$.

Translated by A. Barkhash 